\title{
PERBANDINGAN RESOLUSI SPASIAL, TEMPORAL DAN RADIOMETRIK SERTA KENDALANYA
}

\author{
Oleh : \\ Amelia Oktaviani dan Yarjohan \\ Prodi IImu Kelautan Mahasiwa IImu Kelautan Universitas Bengkulu \\ ${ }^{\star}$ E-mail : ameliaoktaviani049@gmail.com \\ Received August 2016, Accepted August 2016
}

\begin{abstract}
ABSTRAK
Perkembangan zaman yang sangat pesat saat ini mendorong keinginan manusia untuk dapat melakukan kegiatan dan pekerjaan dalam segala bidang kehidupan dengan lancar dan tepat waktu. Salah satunya adalah satelit yang digunakan untuk merekam permukaan bumi. Satelit terdiri dari beberapa resolusi yaitu resolusi spasial yg merupakan ukuran terkecil dari suatu objek, resolusi ini terdiri dari resolusi tinggi (0.6-4 m), menengah $(4-30 \mathrm{~m})$ dan rendah $(30->1000 \mathrm{~m})$. Kemudian resolusi temporal yaitu waktu pengambilan, resolusi ini terdiri dari Resolusi spasial tinggi (0.6-4 m), resolusi spasial menengah (4-30 m), resolusi spasial rendah (30 - > $1000 \mathrm{~m})$. Sedangkan Resolusi Radiometrik adalah kemampuan sensor dalam mencatat respons spektral objek. Resolusi ini berupa 2 bit (0-1), 3 bit (0-3), 4 bit (0-15), 5 bit (0-31), 6 bit (0-63), 7 bit (0-127), 8 bit (0255), 10 bit (0-1023), 16 bit (0-65535).
\end{abstract}

Kata kunci : perbandingan, resolusi spasial, resolusi temporal, resolusi radiometrik, kendala

\section{PENDAHULUAN}

Perkembangan zaman yang sangat pesat saat ini mendorong keinginan manusia untuk dapat melakukan kegiatan dan pekerjaan dalam segala bidang kehidupan dengan lancar dan tepat waktu. Akan tetapi dalam hal ini manusia sering mengalami hambatan yang dikarenakan oleh kurang akuratnya hasil analisis cuaca yang menjadi salah satu sumber informasi yang digunakan oleh manusia dalam memprakirakan cuaca, agar dapat merencanakan dan melaksanakan berbagai kebijakan pekerjaan (Santi, 2011).

Indonesia merupakan negara yang terletak di daerah tropik. Letak tersebut mengakibatkan curah hujan yang diterima cukup tinggi. Di daerah tropik, bentuk presipitasi yang umum terjadi adalah hujan. Di Indonesia penelitian mengenai hujan menjadi penting mengingat seringkalinya timbul persoalan baik yang berkaitan dengan rendahnya curah hujan maupun persoalan tentang curah hujan yang tinggi (Kusmawati, 2008).

Salah satu instrumen yang dapat digunakan untuk memonitor kondisi cuaca adalah satelit. Dengan menggunakan satelit, kondisi cuaca dapat teramati secara spasial dalam ruang lingkup yang cukup luas. Satelit GMS dapat memberikan informasi dari hasil liputannya yaitu memantau permukaan bumi, liputan awan, badai tropik, ENSO, posisi dan gerak ITCZ dan menduga curah hujan. Pemanfaatan satelit cuaca ini dapat pula digunakan untuk melihat sebaran awan di daerah Indonesia. Dengan pengolahan citra satelit dapat ditentukan pula sebaran hujan di berbagai daerah (Kusmawati, 2008). 


\section{Resolusi Spasial}

Merupakan ukuran terkecil obyek di lapangan yang dapat direkam pada data digital maupun pada citra. Pada data digital resolusi dilapangan dinyatakan dengan pixel. Semakin kecil ukuran terkecil yang dapat direkam oleh suatu sistem sensor, berarti sensor itu semakin baik karena dapat menyajikan data dan informasi yang semakin rinci. Resolusi spasial yang baik dikatakan resolusi tinggi atau halus, sedang yang kurang baik berupa resolusi kasar atau rendah (Suwargana,2013).

Resolusi spasial merupakan kemampuan untuk menampakkan dua objek yang berdekatan secara terpisah. Dapat disebut juga daya memecah detail suatu objek. Resolusi spasial dipengaruhi oleh pixel citra tersebut. Semakin banyak pixel dan ukuran pixel yang kecil memberikan detail yang lebih baik, karena setiap pixel akan mewakili informasi suatu citra. Semakin besar matrix pixel maka akan memberikan resolusi spasial yang lebih baik. Resolusi spasial dapat disebabkan juga oleh blur akibat faktor geometris, misalnya karena ukuran fokus tabung, dofusi cahaya pada receptor, bukan diafragma, dan pergerakan pasien. Dalam diagnostik pencitraan digital, resolusi spasial 2,5-5,0 mm merupakan range optimal dalam menghasilkan citra. Untuk mammografi yang membutuhkan detail tinggi ketika ada mikro kalsifikasi, ataupun tulang yang membutuhkan detail maka dibutuhkan resolusi spasial yang lebih tinggi. Dalam pencitraan $\mathrm{CR}$ penyebab resolusi spasial yang rendah adalah karena hamburan cahaya saat imaging plate dibaca. Kejadian ini dapat mengakibatkan blur pada saat imaging plate dibaca oleh imaging plate reader (Setyawan, 2014).

Dalam menentukan range resolusi, ada tiga tingkat ukuran resolusi yang perlu diketahui, yaitu:

a. Resolusi spasial tinggi, berkisar : 0.6-4 m.

b. Resolusi spasial menengah, berkisar : 4-30 m

c. Resolusi spasial rendah, berkisar : 30 - > 1000 m (Suwargana, 2013).

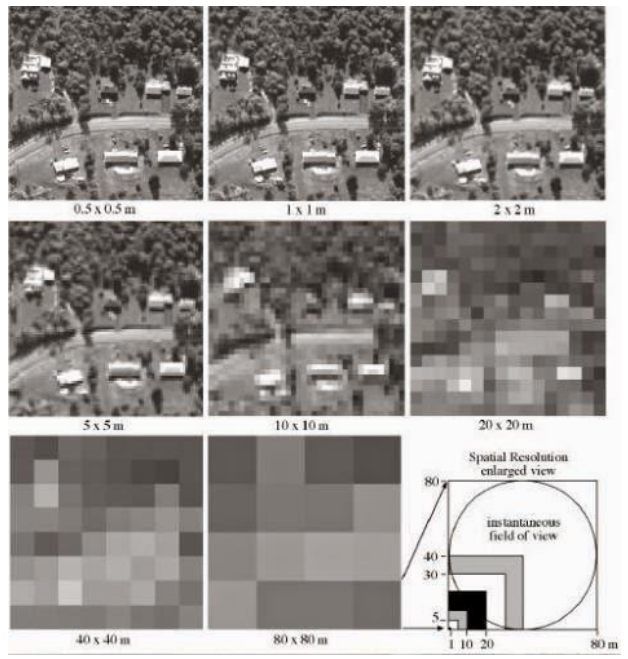

Gambar 1.1 Hasil Perbedaan Resolusi Spasial

Beberapa contoh satelit bumi yang mempunyai resolusi spasial adalah:

a. Landsat : 15 meter pada mode pankromatik dan 30 meter pada mode multispektral 
b. Spot : 10 meter pada mode pankromatik dan 20 meter pada mode multispektral c. Ikonos : 1 meter pada mode pankromatik dan 4 meter pada mode multispektral (Suwargana, 2013).

Berikut adalah resolusi spasial pada beberapa jenis citra :

- Citra SPOT resolusi spasialnya 10 dan 20 meter

- Citra Landsat TM resolusi spasialnya 30 meter

- Citra Landsat MSS resolusi spasialnya 79 meter

- Citra IKONOS resolusi spasialnya 1.5 meter, diluncurkan pertama kali pada tanggal 24 September 1999 oleh Space Imagine, merupakan citra satelit komersil pertama.

- Citra QuickBird resolusi spasialnya yang tertinggi saat ini yaitu 0.61 meter. Diluncurkan pada tanggal 18 Oktober 2001 oleh Digital Globe.

- Citra OrbView 3 resolusi spasialnya adalah 1 meter (pankromatik) dan 4 meter (multispektral). Diluncurkan pada 26 juni 2003 oleh GeoEye.

- Formosat 2 resolusi spasialnya adalah 2 meter (pankromatik) dan 8 meter (multispektral) (Sugiarto, 2012).

\section{Resolusi Temporal}

Resolusi temporal diartikan sebagai lamanya waktu bagi sensor satelit untuk mengindera daearah yang sama untuk yang kedua kalinya. Satuannya biasanya adalah hari. Semakin banyak jumlah hari yang diperlukan untuk mengindera daerah yang sama maka semakin rendah resolusi temperolanya, dan sebaliknya (Syah,2010).

Resolusi temporal ialah frekuensi perekaman ulang kembali ke daerah yang sama pada rentang waktu tertentu. Rentang waktu perulangan ke asal daerah yang sama satuannya dinyakan dalam jam atau hari, contoh resolusi temporal ini: a. Resolusi temporal tinggi berkisar antara : $<24$ jam - 3 hari. b. Resolusi temporal sedang berkisar antara : 4-16 hari c. Resolusi temporal rendah berkisar antara:> 16 hari (Suwargana, 2013).

Bebarapa contoh satelit bumi yang mempunyai resolusi temporal:

a. Landsat generasi $1: 18$ hari

b. Landsat generasi 2 : 16 hari

c. SPOT : 26 hari atau 6-7 kali/bulan karena sensor dapat ditengokkan arah perekamannya d. Ikonos: antara 1,5 sampai 3 hari (Suwargana, 2013). 


\section{BEBERAPA SENSOR INDERAJA}

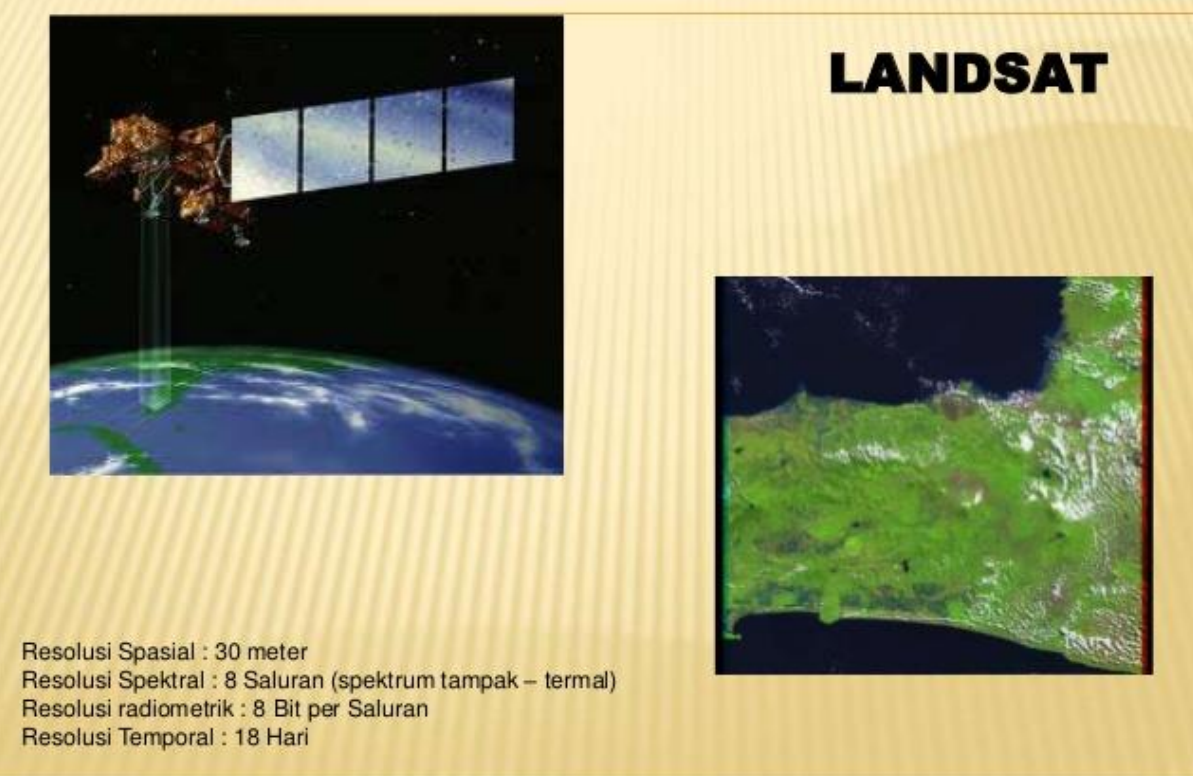

Gambar 1.3 Hasil Sensor Resolusi Temporal oleh LANDSAT generasi 1 :18 hari.

\section{Resolusi Radiometrik}

Resolusi radiometrik dapat diartikan sebagai julat (range) representasi/kuantisasi data, yang biasanya dipergunakan untuk format raster. Julat tersebut dapat berupa 2 bit (0-1), 3 bit (0-3), 4 bit (0-15), 5 bit (0-31), 6 bit (063), 7 bit (0-127), 8 bit (0-255), 10 bit (0-1023), 16 bit (0-65535). Semakin besar bit yang dimiliki oleh suatu sensor, maka sesnsor tersebut dapat dikatakan mempunyai resolusi radiometrik yang tinggi (Syah,2010).

Resolusi radiometrik ialah kemampuan sensor dalam mencatat respons spektral objek. Sensor yang peka dapat membedakan selisih respons yang paling lemah sekalipun. Kemampuan sensor ini secara langsung dikaitkan dengan kemampuan koding, yaitu mengubah intensitas pantulan atau pancaran spektral menjadi angka digital. Kemampuan ini dinyatakan dalam bit. Landsat 7 ETM+ memiki resolusi radiometrik sebesar 8 bit yang berarti 256 tingkat kecerahan (0255), 0 untuk sinyal terlemah (hitam) dan 255 untuk sinyal terkuat (putih). Berbeda halnya dengan Landsat 8 OLI yang memiliki resolusi radiometrik sebesar 16 bit yang berarti 65536 tingkat kecerahan 0 untuk sinyal terlemah (hitam) dan 65535 untuk sinyal terkuat (putih). Hal tersebut menjelaskan bahwa Landsat 8 OLI memiliki resolusi radiometrik lebih tinggi dibandingkan Landsat 7 ETM+. Semakin tinggi resolusi radiometrik yang dimiliki maka akan semakin tinggi pula kemampuan untuk membedakan objek-objek di permukaan bumi (Hernan, 2016). 


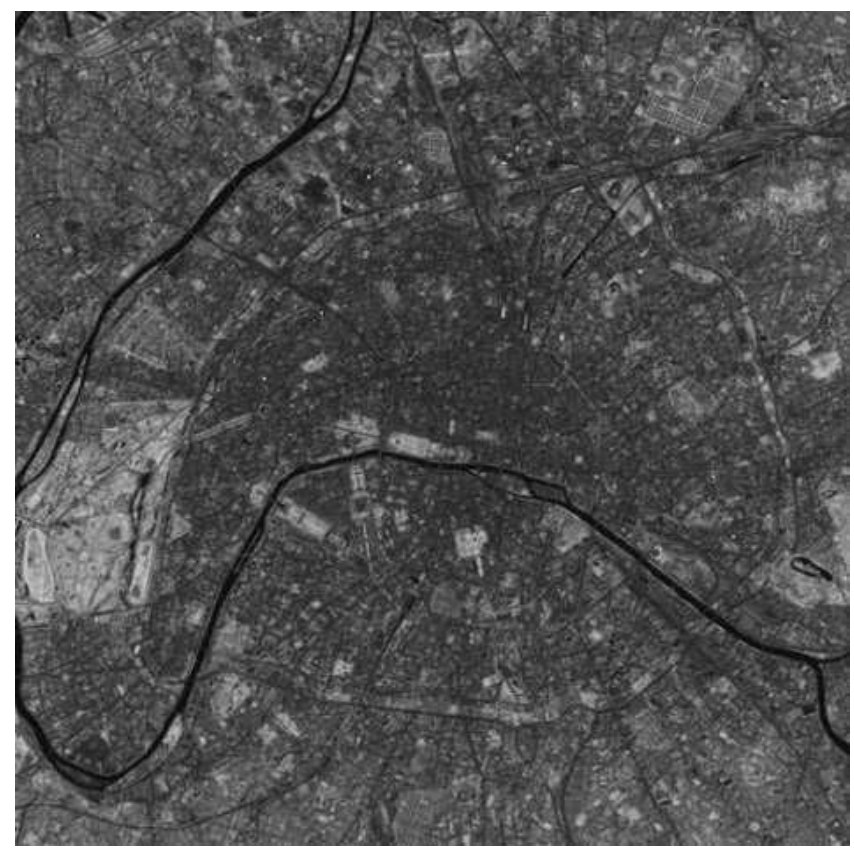

[from 0-255]

Gambar 1.4 Hasil Sensor Resolusi Radiometrik 8 bits $=256$ pixel value

\section{Kendala Resolusi}

Meskipun benar bahwa resolusi yang tinggi akan memberikan data yang lebih banyak, tetapi itu tidak sinonim dengan meningkatnya jumlah informasi yang diperoleh. Dari segi teknis, pemakai dihadapkan pada pilihan untuk mengoptimalkan resolusi (spasial, temporal, spektral dan radiometrik), biaya untuk mendapatkan data, dan pengolahan data tersebut. Meningkatnya resolusi membawa konsekuensi meningkatnya jumlah data yang harus diperoleh. MSS yang mengkover $185 \mathrm{~km} \times 170 \mathrm{~km}$ dengan resolusi $79 \mathrm{~m} \times 79 \mathrm{~m}, 4$ band dengan resolusi radiometrik 7 bit untuk band 4,5 dan 7 serta 6 bit untuk band 6 membutuhkan ruang $24 \mathrm{MB}$, sementara TM yang mencakup areal yang sama, dengan resolusi $30 \mathrm{~m} \times 30 \mathrm{~m}, 7$ band dan 8 bit membutuhkan $227 \mathrm{MB}$. Berangkat dari hal di atas, maka pemilihan resolusi perlu disesuaikan dengan obyek atau fenomena masalah yang dihadapi serta biaya yang tersedia (Forester, 2016).

\section{KESIMPULAN}

Sistem penginderaan jauh ini memiliki macam-macam resolusi yang terdiri dari resolusi spasial,temporal dan radiometrik. Resolusi spasial adalah ukuran terkecil obyek di lapangan yang dapat direkam pada data digital maupun pada citra. Pada data digital resolusi dilapangan dinyatakan dengan pixel. Tingkat resolusi spasial terdiri dari resolusi spasial tinggi berkisar : 0.6-4 m, menengah berkisar : 4-30 m dan rendah berkisar : $30->1000 \mathrm{~m}$. Resolusi spasial ini terdapat pada beberapa citra yaitu LANDSAT, SPOT,IKONOS, dan lain-lain. Sedangkan resolusi temporal adalah lamanya waktu bagi sensor satelit untuk mengindera daearah yang sama untuk yang kedua kalinya, dan resolusi ini hanya terdapat pada LANDSAT dan SPOT saja. resolusi temporal terdiri dari resolusi temporal tinggi berkisar antara : $<24$ jam - 3 hari. Resolusi temporal sedang berkisar antara : 4-16 hari. Resolusi temporal rendah berkisar antara:> 16 hari. Sedangkan 
resolusi Radiometrik adalah julat (range) representasi/kuantisasi data, yang biasanya dipergunakan untuk format raster. Julat tersebut dapat berupa 2 bit (0$1), 3$ bit (0-3), 4 bit (0-15), 5 bit (0-31), 6 bit (0-63), 7 bit (0-127), 8 bit (0-255), 10 bit (0-1023), 16 bit (0-65535). Semakin besar bit yang dimiliki oleh suatu sensor, maka sesnsor tersebut dapat dikatakan mempunyai resolusi radiometrik yang tinggi. Sedangkan kendalanya menggunakan resolusi citra ini adalah biaya untuk mendapatkan data, dan pengolahan data tersebut. Meningkatnya resolusi membawa konsekuensi meningkatnya jumlah data yang harus diperoleh. MSS yang mengkover $185 \mathrm{~km} \times 170 \mathrm{~km}$ dengan resolusi $79 \mathrm{~m} \times 79 \mathrm{~m}, 4$ band dengan resolusi radiometrik 7 bit untuk band 4, 5 dan 7 serta 6 bit untuk band 6 membutuhkan ruang $24 \mathrm{MB}$, sementara TM yang mencakup areal yang sama, dengan resolusi $30 \mathrm{~m} \times 30 \mathrm{~m}, 7$ band dan 8 bit membutuhkan $227 \mathrm{MB}$.

\section{DAFTAR PUSTAKA}

Forester,A. 2016. Dsiplay Citra Digital Penginderaan Jauh (Bab I). Http://Www.Forester.Id/2016/03/Display-Citra-Digital-PenginderaanJauh.Html. Diakses Tanggal 10 Oktober 2016. Pukul : 23.50

Hernan. 2016. Konsep Resolusi Dalam Penginderaan Jauh. Https://Hernandeaff.Wordpress.Com/2016/02/29/Konsep-Resolusi-DalamPenginderaan-Jauh-Spasial-Spektral-Radiometrik-Temporal/. Diakses Tanggal 11 Oktober 2016. Pukul : 07.46

Kusmawati, Y. 2008. Variasi Spasial Dan Temporal Hujan Konvektif Di Pulau Jawa Berdasarkan Citra Satelit. Jurnal Agromet Indonesia. 22(1) : 1-14.

Syah, A.F. 2010. Penginderaan Jauh Dan Aplikasinya Di Wilayah Pesisir Dan Lautan. Jurnal Kelautan. 3(1). 18-28

Santi,R.C.N. 2011. Teknik Perbaikan Kualitas Citra Satelit Cuaca Dengan Sataid. Jurnal Teknologi Informasi Dinamik. 16(2) : 101-109

Setyawan, H.T. 2014. Uji Resolusi Spasial Pada Perangkat Lunak Computed Radiography Menggunakan Pengolahan Citra Digital. Youngster Physics Journal. 3(4) : 311-316

Sugiarto, D.P. 2012. Menilai Keunggulan Resolusi Citra. Https://Tnrawku.Wordpress.Com/2012/03/25/Menilai-Keunggulan-ResolusiCitra/. Diakses Tanggal 08 Oktober 2016. Pukul : 20.00

Suwargana, N. 2013. Resolusi Spasial, Temporal Dan Spektral Pada Citra Satelit Landsat, Spot Dan Ikonos. Jurnal IImiah Widya. 1(2) : 167-174 